\title{
Chemical Constituents and Autoxidative Stability of Milk Lipids of Kankrej Cow
}

\author{
Minal Bharwade*, Smitha Balakrishnan and Nisha Chaudhary
}

Dairy Chemistry Department, SMC College of Dairy Science, AAU, Anand, India

*Corresponding author

Keywords

Kankrej milk fat,

Unsaponifiable matter,

Cholesterol, $\beta$-Carotene,

Vitamin A, Moisture and free fatty acids

Article Info

Accepted:

16 February 2018

Available Online:

10 March 2018

\section{A B S T R A C T}

Various chemical constituents of Kankrej milk fat namely moisture, free fatty acids, carbonyl value and unsaponifiable matter were analyzed in the present study for a period of 12 months. The average unsaponifiable content of Kankrej milk fat sample was 423 $\mathrm{mg} / 100 \mathrm{~g}$, while cholesterol content was found to be $320 \mathrm{mg} / 100 \mathrm{~g}$. $\beta$-Carotene content of Kankrej milk fat was observed to be lower $(2.9 \mu \mathrm{g} / \mathrm{g})$ while vitamin A level of Kankrej milk fat was observed to be higher $(34.5 \mathrm{IU} / \mathrm{g}$ ) than those reported for other indigenous breeds. An average moisture content of Kankrej milk fat sample was 0.19 per cent, while free fatty acids content was found to be 0.20 per cent. Total carbonyl value of Kankrej milk fat was $4.9 \mu \mathrm{M} / \mathrm{g}$ of milk fat. Autoxidative study at accelerated storage conditions $\left(80 \pm 1^{\circ} \mathrm{C}\right)$ revealed that Kankrej milk fat showed better oxidative stability may be due to lower content of unsaturated fatty acids. The average value for unsaponifiable and cholesterol content in Kankrej milk fat was highest during November to February while levels of $\beta$-carotene and vitamin A were higher during July to October reflecting seasonal variations.

\section{Introduction}

Kankrej breed of cattle is one of the 26 recognized cattle breed (Bos indicus) of India. They are one of the heaviest dual purpose breed in India. The breed originated in north Gujarat in the erstwhile Bombay province of India. They takes their name from geographical area i.e. Kankrej taluka of Banaskantha district in Gujarat. They are found in the area southeast of Rann of Kutch comprising Mehsana, Ahmedabad, Kheda, Anand, Sabarakantha and Banaskantha districts of Gujarat and Barmer and Jodhpur districts of Rajasthan. Milk fat obtained from
Kankrej cow shows seasonal variation in chemical constituents in which unsaponifiable matter includes cholesterol, carotene and vitamins.

The unsaponifiable matter which can be obtained from oils and fats after saponification with alkali and subsequent extraction by a suitable organic solvent constitutes less than 2 per cent by weight of fat. It is a repository of so many valuable constituents, like sterols (cholesterol and phytosterols), fat-soluble vitamin (A, D, E and $\mathrm{K}$ ), hydrocarbons such as squalene, pigments, etc. Milk fat contains unsaponifiable matter in the range of 0.30 to 
0.45 per cent by weight (Jenness and Patton, 1969) chiefly consisting of cholesterol ( 0.25 to 0.40 per cent by weight of fat). Cholesterol is the major constituent of the unsaponifiable matter of milk fat. It exists both in the esterified and in free forms.

Carotene is a chief colouring material in milk fat, although other related carotenoids (Xanthophyll) are present in small amount. Carotene is derived from green plant sources in the feed of the lactating cow, which is the only mammal to transfer such colour to milk fat. It is found free from chemical combination in milk fat. It is stable to oxidative agents but in fat it may be oxidized and bleached under unfavourable storage conditions. Carotene present in milk fat is of considerable importance as a precursor of vitamin A. further, it plays an important role in the autoxidative stability of milk fat (Kempanna and Unnikrishnn, 1986; Surendra Nath and Rama Murthy, 1983).

Ghee owes its pleasing flavour to several free fatty acids (FFA). These compounds are produced from fatty acid glycerides by the mechanism involving lipolysis (through lactic streptococci)/hydrolysis during the fermentation of milk or cream and/or processing treatments while preparing ghee (Wadhwa and Jain, 1990).

Carbonyls play an important role in contributing to the flavour of ghee. This class of compounds includes, broadly, monocarbonyls and dicarbonyls. Monocarbonyls further constitute alkan-2ones (90 per cent), alkanals ( 6 per cent), alk-2enals ( 2 per cent) and alk-2, 4-dienals ( 2 per cent). Alkan-2-ones are produced by the hydrolysis of ketonogenic glycerides ( $\beta$-keto glycerides) followed by decarboxylation of $\beta$ keto carboxylic acids during various processing treatments involved in the preparation of ghee (Wadhwa and Jain, 1989).

\section{Materials and Methods}

\section{Feeding and management of animals}

Milk samples were collected from group of pure breed of Kankrej cow maintained at the LRS (Livestock research station), Anand Agricultural University, Anand. The herd consisted of 18 cows at different stages of lactation. The cows were fed ad libitium amount of mixed green fodder consisting of maize, sorghum and Napier grass (Coimbatore-2) during summer and monsoon under farm conditions.

During summer the proportion of Napier grass fed to the animal was relatively high compared to other seasons. During winter along with sorghum sunflower, oats and cowpea was also fed. The proportion of legume, cowpea was more than 70 per cent of total green fodder during winter. The cows were also given concentrate (Amul dhan) at the rate of $0.5 \mathrm{~kg} /$ litre of milk / day. During all season sorghum hay was fed. Each animal was fed $17-18 \mathrm{~kg}$ of dry matter/ day.

\section{Collection of milk sample}

The pooled Kankrej cow milk sample was collected at 15 days interval from Livestock Research Station (LRS), AAU, Anand for a period of one year, from March 2016 to February 2017. Total 24 replications for milk of Kankrej cow were carried out. All cows were maintained under identical conditions of feeding and management. The feed given to animals throughout the year consisted of normal concentrate and roughages.

\section{Preparation of ghee sample}

The milk sample were warmed to $40^{\circ} \mathrm{C}$ and then separated into cream using cream separator. Ghee sample was prepared in laboratory by direct cream method (Heat 
clarification at $120^{\circ} \mathrm{C} /$ no hold). Ghee was then filtered through 6-8 fold muslin cloths followed by Whatman No. 4 filter paper, filled in glass bottles, cool to room temperature and kept in a refrigerator at a temperature of $7 \pm 1^{\circ} \mathrm{C}$ till further analysis.

\section{Analysis of ghee}

Ghee samples were analysed for Chemical constituents such as unsaponifiabe matter in which cholesterol; $\beta$-Carotene and vitamin A content, moisture content, free fatty acids, carbonyl value and also peroxide value by using the method specified in BIS (1981).

\section{Statistical analysis of data}

The data were analysed using Completely Randomized Design (CRD), while data on storage studies were analysed by two factorial CRD as per the methods described by Steel and Torrie (1980).

\section{Results and Discussion}

Various chemical constituents of Kankrej milk fat namely unsaponifiable matter, moisture, free fatty acids and carbonyl value and as well as autoxidative stability were analyzed in the present study for a period of 12 months. The unsaponifiable matters namely cholesterol content, vitamin $\mathrm{A}$ and $\beta$-carotene were determined for Knakrej milk fat. The results and findings are discussed below.

\section{Unsaponifiable matter}

The unsaponifiable matter consists mainly of cholesterol, carotene, vitamin A, D, E and $\mathrm{K}$ certain sterols and hydrocarbons such as squalene. Milk fat contains unsaponifiable matter in the range of 0.30 to 0.45 per cent by weight (Jenness and Patton, 1969) chiefly consisting of cholesterol ( 0.25 to 0.40 per cent by weight of fat).
The unsaponifiable content of Kankrej milk fat sample ranged from 415 to $435 \mathrm{mg} / 100 \mathrm{~g}$ with an average $423 \mathrm{mg} / 100 \mathrm{~g}$ (Table 1).

Deshpande et al., (2008) found unsaponifiable matter content of $780 \mathrm{mg} / 100 \mathrm{~g}$ in cow milk fat while Dhurvey et al., (2012) reported unsaponifiable matter of $923 \mathrm{mg} / 100 \mathrm{~g}$ of cow ghee.

Unsaponifiable matter in Kankrej milk fat was comparable with the values reported reported by other authors.

It also showed seasonal variations the average value for unsaponifiable matter content was highest during November to February (432.7 $\mathrm{mg} / 100 \mathrm{~g}$ ) and lowest during the period from March to June (415 mg/100g), while it has $421.7 \mathrm{mg} / 100 \mathrm{~g}$ during the period from July to October for Kankrej milk fat (Table 2).

Sharma (1989) in his study reported that cow ghee contained higher level of unsaponifiable matter in winter which was 444 to $574 \mathrm{mg} / 100$ $\mathrm{g}$; average, $507 \mathrm{mg} / 100 \mathrm{~g}$ and lower level in summer 422 to $548 \mathrm{mg} / 100 \mathrm{~g}$; average, 475 $\mathrm{mg} / 100 \mathrm{~g}$.

The observed result of unsaponifiable matter in the present study is similar to the values reported in the literature.

\section{Cholesterol}

The average cholesterol content of Kankrej milk fat samples was found to be $320 \mathrm{mg} / 100 \mathrm{~g}$ with a range of 318 to $334 \mathrm{mg} / 100 \mathrm{~g}$. It was also observed that bulk of the unsponifiable matter was constituted with cholesterol (Table 1); on an average, 75.80 per cent of unsaponifiable matter was cholesterol. The cholesterol content of Kankrej milk fat was not high and was comparable with the values reported by other researchers (Kumar et al., 2010; German and Dillard, 2013). 
It can be seen from Table 2 that the average value for cholesterol content was highest during the period from November to February $(327.2 \mathrm{mg} / 100 \mathrm{~g})$ and lowest during the period from July to October which is $316 \mathrm{mg} / 100 \mathrm{~g}$, while an average cholesterol content of 319 $\mathrm{mg} / 100 \mathrm{~g}$ was observed during March to June for Kankrej milk fat.

Bindal and Jain (1973) in their study reported cholesterol content of $342.6 \mathrm{mg} / 100 \mathrm{~g}$ in spring (March to May), $315.3 \mathrm{mg} / 100 \mathrm{~g}$ in summer (June to August,), $330.6 \mathrm{mg} / 100 \mathrm{~g}$ in autumn and $340.8 \mathrm{mg} / 100 \mathrm{~g}$ of cow milk fat in winter (December to February). They correlated higher content of cholesterol during winter and spring season to high proportion of leguminous feed given to animals during these seasons.

In case of Kankrej cows they were fed more proportion of cow pea and oats during November to February and inclusion of higher proportion of leguminous fodder have resulted in higher observed cholesterol levels during this period and as observed by Bindal and Jain (1973).

\section{$\beta$-carotene and vitamin $A$}

The average $\beta$-carotene and vitamin A content of Kankrej milk fat sample was found to be $2.9 \mu \mathrm{g} / \mathrm{g}$ with a range from 2.4 to $3.7 \mu \mathrm{g} / \mathrm{g}$ and $34.5 \mathrm{IU} / \mathrm{g}$ with a range from 24.5 to 45.0 $\mathrm{IU} / \mathrm{g}$, respectively (Table 3 ).

From the data given by Kumar et al., (2010); Rafalowski et al., (2014) we can say that $\beta$ Carotene content in Kankrej cow milk fat is lower $(3.0 \mu \mathrm{g} / \mathrm{g})$ than that reported in literature. The probable reason can be attributed to higher bioconversion of $\beta$ carotene to vitamin $A$ in Kankrej cow. Assuming a bioconversion of $\beta$-carotene to retinol of 1:0.3 (FAO/WHO, 1988) or 1:0.5 (Institute of Medicine (IOM), 2001), it can be calculated that $\beta$-carotene contributes $20 \%$ to the vitamin A activity in milk according to the FAO/WHO conversion factors or $33 \%$ according to the IOM conversion factors.

Breed appears to be one of the major factors affecting the carotene level of milk fat; other important factor being feed. In our case $\beta$ carotene content during July to October was higher compared to rest of the period of study. This may be due to availability of more carotene in the green fodder during rainy season. The level of vitamin A observed for Kankrej milk fat in the present study is on higher $(34.5 \mathrm{IU} / \mathrm{g})$ side of the values reported for milk fat of other breeds of cattle. The probable reason can be attributed to higher content of $\beta$-carotene in the milk fat during these periods resulting in higher bioconversion to vitamin $\mathrm{A}$.

It can be seen from Table 4 that the average value for $\beta$-Carotene and vitamin A content in Kankrej milk fat was highest during the period from July to October $(3.4 \mu \mathrm{g} / \mathrm{g}$ and $44.2 \mathrm{IU} / \mathrm{g}$ respectively) and lowest during November to February $(2.5 \mu \mathrm{g} / \mathrm{g}$ and $24.6 \mathrm{IU} / \mathrm{g})$ i.e. winter season. During the period from March to June, the mean value of $\beta$-Carotene $(2.9 \mu \mathrm{g} / \mathrm{g})$ and vitamin A (24.60 IU/g) content in Kankrej milk fat was in range between the above two periods.

In the present study highest $\beta$-carotene and vitamin A content was observed during the month of July to October i.e. rainy season. Although almost same type and quantity of green fodder was fed to the animals during the period March to June (summer season) and July to October (rainy season), the carotene and vitamin A content was higher during July to October. This can be very well justified by the fact that carotene content is not only influenced by the quantity of green fodder but also by the carotene present in green fodder fed to the animals. 
Table.1 Unsaponifiable matter and cholesterol contents in Kankrej milk fat

\begin{tabular}{|l|c|c|c|}
\hline Period & $\begin{array}{c}\text { Unsaponifiable } \\
\text { matter }(\mathbf{m g} / \mathbf{1 0 0} \mathbf{g})\end{array}$ & $\begin{array}{c}\text { Cholesterol } \\
(\mathbf{m g} / \mathbf{1 0 0} \mathbf{g})\end{array}$ & $\begin{array}{c}\text { Proportion of cholesterol } \\
\text { in unsaponifiable matter } \\
(\boldsymbol{\%})\end{array}$ \\
\hline March 2016 & 415 & 319 & 76.86 \\
\hline A pril 2016 & 415 & 319 & 76.86 \\
\hline May 2016 & 415 & 318 & 76.62 \\
\hline June 2016 & 415 & 320 & 77.10 \\
\hline July 2016 & 425 & 314 & 73.88 \\
\hline August 2016 & 422 & 317 & 75.11 \\
\hline September 2016 & 420 & 318 & 75.71 \\
\hline October 2016 & 420 & 315 & 75.00 \\
\hline November 2016 & 435 & 320 & 73.56 \\
\hline December 2016 & 435 & 322 & 74.02 \\
\hline January 2017 & 430 & 333 & 77.44 \\
\hline February 2017 & 431 & 334 & 77.49 \\
\hline A verage & 423 & 320 & - \\
\hline SEm士 & 0.8 & 1.0 & - \\
\hline CD (0.05) & 2.5 & 3.0 & - \\
\hline CV \% & 0.2 & 0.4 & \\
\hline
\end{tabular}

Table.2 Seasonal variations in unsaponifiable matter and cholesterol

\begin{tabular}{|c|c|c|c|}
\hline Period & $\begin{array}{c}\text { Unsaponifiable } \\
\text { matter* }(\mathbf{m g} / \mathbf{1 0 0 g})\end{array}$ & $\begin{array}{l}\text { Cholesterol* } \\
\text { (mg/100g) }\end{array}$ & $\begin{array}{c}\text { Proportion of cholesterol } \\
\text { in unsaponifiable matter* } \\
(\%)\end{array}$ \\
\hline $\begin{array}{l}\text { March } 2016 \\
\text { to June } 2016 \\
\text { (Summer } \\
\text { season) }\end{array}$ & $415.0^{b}$ & $319.0^{b}$ & 76.6 \\
\hline $\begin{array}{c}\text { July } 2016 \\
\text { to October } \\
2016 \\
\text { (Rainy season) }\end{array}$ & $421.7^{\mathrm{a}}$ & $316.0^{\mathrm{a}}$ & 74.9 \\
\hline $\begin{array}{c}\text { November } 2016 \\
\text { to } \\
\text { February } 2017 \\
\text { (Winter season) } \\
\end{array}$ & $432.7^{c}$ & $327.2^{c}$ & 75.6 \\
\hline SEm \pm & 0.7 & 1.4 & - \\
\hline CD (0.05) & 2.1 & 4.3 & - \\
\hline CV \% & 0.4 & 1.3 & - \\
\hline
\end{tabular}


Table.3 $\beta$ - Carotene and vitamin A content in Kankrej milk fat

\begin{tabular}{|l|c|c|}
\hline Period & $\begin{array}{c}\boldsymbol{\beta}-\text { Carotene } \\
(\mu \mathrm{g} / \mathrm{g})\end{array}$ & Vitamin A (IU/g) \\
\hline March 2016 & 3.0 & 33.5 \\
\hline April 2016 & 3.0 & 33.5 \\
\hline May 2016 & 3.0 & 37.5 \\
\hline June 2016 & 3.0 & 35.0 \\
\hline July 2016 & 3.1 & 45.0 \\
\hline August 2016 & 3.6 & 43.0 \\
\hline September 2016 & 3.5 & 45.5 \\
\hline October 2016 & 3.7 & 43.0 \\
\hline November 2016 & 2.5 & 24.5 \\
\hline December 2016 & 2.6 & 24.5 \\
\hline January 2017 & 2.5 & 25.0 \\
\hline February 2017 & 2.4 & 24.5 \\
\hline Average & 2.9 & 34.5 \\
\hline SEm & 0.1 & 1.4 \\
\hline CD (0.05) & 0.2 & 4.3 \\
\hline CV \% & 3.8 & 5.7 \\
\hline
\end{tabular}

Table.4 Seasonal variation in $\beta$-carotene and vitamin $A$

\begin{tabular}{|c|c|c|}
\hline Period & $\boldsymbol{\beta}-\underset{(\mu \mathrm{g} / \mathrm{g})}{\text { Carotene* }}$ & Vitamin $A^{*}(I U / g)$ \\
\hline $\begin{array}{l}\text { March } 2016 \text { to June } 2016 \\
\text { (Summer season) }\end{array}$ & $2.90^{b}$ & $34.80^{\mathrm{b}}$ \\
\hline $\begin{array}{l}\text { July } 2016 \text { to October } 2016 \\
\text { (Rainy season) }\end{array}$ & $3.40^{\mathrm{c}}$ & $44.20^{\mathrm{c}}$ \\
\hline $\begin{array}{l}\text { November } 2016 \text { to February } \\
2017 \\
\text { (Winter season) }\end{array}$ & $2.50^{\mathrm{a}}$ & $24.60^{\mathrm{a}}$ \\
\hline SEm \pm & 0.05 & 0.68 \\
\hline CD (0.05) & 0.17 & 2.00 \\
\hline CV \% & 5.53 & 5.58 \\
\hline \multicolumn{3}{|c|}{$\begin{array}{l}\text { The values are average of samples collected during four months for } \\
\text { each period } \\
\text { Values within columns (treatments) with same lowercase superscript did } \\
\text { not differ significantly }(\mathbf{P}<0.05) \text { from each other }\end{array}$} \\
\hline
\end{tabular}


Table.5 Moisture, free fatty acids content and Total carbonyl value in Kankrej milk fat

\begin{tabular}{|l|c|c|c|}
\hline Period & $\begin{array}{c}\text { Moisture content } \\
(\boldsymbol{\%})\end{array}$ & $\begin{array}{c}\text { Free fatty acids* } \\
(\boldsymbol{\%} \text { oleic acid) }\end{array}$ & $\begin{array}{c}\text { Total carbonyl } \\
\text { value }(\boldsymbol{\mu m} / \mathbf{g})\end{array}$ \\
\hline March 2016 & 0.19 & 0.20 & 4.70 \\
\hline Apri 2016 & 0.19 & 0.20 & 4.85 \\
\hline May 2016 & 0.19 & 0.20 & 4.75 \\
\hline June 2016 & 0.20 & 0.20 & 4.85 \\
\hline July 2016 & 0.20 & 0.20 & 5.25 \\
\hline August 2016 & 0.20 & 0.20 & 5.55 \\
\hline September 2016 & 0.20 & 0.20 & 5.25 \\
\hline October 2016 & 0.20 & 0.20 & 5.25 \\
\hline November 2016 & 0.20 & 0.20 & 4.60 \\
\hline December 2016 & 0.20 & 0.20 & 4.63 \\
\hline January 2017 & 0.20 & 0.20 & 4.73 \\
\hline February 2017 & 0.20 & 0.20 & 4.94 \\
\hline A verage & 0.19 & 0.20 & 4.94 \\
\hline SEm & 0.01 & 0.00 & 0.16 \\
\hline CD (0.05) & NS & NS & 0.49 \\
\hline CV \% & 3.58 & 0.07 & 4.58 \\
\hline NS: non-significant & & & \\
\hline
\end{tabular}

Table.6 Rate of autoxidation of Kankrej milk fat stored at $80 \pm 1^{\circ} \mathrm{C}$

\begin{tabular}{|c|c|c|c|c|c|c|c|c|c|c|c|}
\hline \multirow{3}{*}{$\begin{array}{l}\text { Treatments } \\
\text { (Milk fat } \\
\text { samples) }\end{array}$} & \multicolumn{10}{|c|}{ Storage period (Days) } & \multirow{3}{*}{$\begin{array}{l}\text { Average of } \\
\text { treatments }\end{array}$} \\
\hline & 1 & 2 & 3 & 4 & 5 & 6 & 7 & 8 & 9 & 10 & \\
\hline & \multicolumn{10}{|c|}{ Peroxide value (millimoles of $\mathrm{O}_{2} / \mathrm{kg}$ of fat) } & \\
\hline March 2016 & 0.1 & 0.29 & 0.42 & 0.62 & 0.85 & 1.25 & 1.52 & 1.84 & 2.25 & 2.60 & 1.17 \\
\hline April 2016 & 0.1 & 0.26 & 0.43 & 0.62 & 0.86 & 1.25 & 1.53 & 1.81 & 2.24 & 2.60 & 1.17 \\
\hline May 2016 & 0.1 & 0.26 & 0.42 & 0.63 & 0.86 & 1.20 & 1.55 & 1.83 & 2.24 & 2.60 & 1.17 \\
\hline June 2016 & 0.1 & 0.27 & 0.42 & 0.63 & 0.86 & 1.25 & 1.53 & 1.85 & 2.23 & 2.59 & 1.17 \\
\hline July 2016 & 0.1 & 0.29 & 0.44 & 0.64 & 0.85 & 1.25 & 1.55 & 1.85 & 2.24 & 2.65 & 1.18 \\
\hline August 2016 & 0.1 & 0.29 & 0.47 & 0.66 & 0.86 & 1.24 & 1.54 & 1.87 & 2.27 & 2.64 & 1.19 \\
\hline September 2016 & 0.1 & 0.29 & 0.45 & 0.68 & 0.87 & 1.26 & 1.57 & 1.85 & 2.27 & 2.63 & 1.20 \\
\hline October 2016 & 0.1 & 0.3 & 0.45 & 0.67 & 0.87 & 1.28 & 1.58 & 1.86 & 2.28 & 2.67 & 1.20 \\
\hline November 2016 & 0.1 & 0.28 & 0.44 & 066 & 0.85 & 1.25 & 1.55 & 1.84 & 2.27 & 2.64 & 1.19 \\
\hline December 2016 & 0.1 & 0.28 & 0.47 & 0.62 & 0.84 & 1.25 & 1.54 & 1.88 & 2.26 & 2.62 & 1.18 \\
\hline January 2017 & 0.1 & 0.27 & 0.48 & 0.63 & 0.84 & 1.26 & 1.55 & 1.87 & 2.25 & 2.62 & 1.18 \\
\hline February 2017 & 0.1 & 0.27 & 0.45 & 0.62 & 0.86 & 1.25 & 1.54 & 1.84 & 2.27 & 2.63 & 1.18 \\
\hline A verage of PV & 0.1 & 0.28 & 0.44 & 0.64 & 0.85 & 1.25 & 1.54 & 1.85 & 2.25 & 2.62 & 1.18 \\
\hline \multicolumn{12}{|c|}{$\mathrm{CD}(0.05) \mathrm{T}=\mathrm{NS} ; \mathrm{P}=\mathrm{NS} ; \mathrm{TxP}=\mathrm{NS}$} \\
\hline 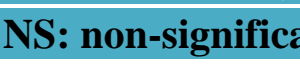 & & & & & & & & & & & \\
\hline
\end{tabular}


As reported by Hulshof et al., (2006) carotene content in the plant is subjected to seasonal variations; decreases during summer and is highest during rainy season. The reason for higher content can be correlated to availability of high carotene content in the green fodder fed to the animals during the period July to October i.e. rainy season. Subsequently, a higher content of $\beta$-carotene paved way for greater bioconversion into vitamin A resulting in its increased average content during July to October.

\section{Moisture Content}

The moisture content of the Kankrej milk fat sample was in the range of 0.19 to 0.20 per cent with an average 0.19 per cent (Table 5). Thus, the Kankrej milk fat samples meet the standards for moisture given by FSSA (2011) (maximum permitted value is 0.5 per cent) and AG Mark (1938) (maximum permitted value is 0.3 per cent). The moisture content was not affected by seasons.

Changade et al., (2006) reported that moisture content of 0.24 per cent in ghee. Meghwal et al., (2012) reported moisture content of 0.122 per cent in cow ghee.

The presence of moisture accelerates the hydrolysis of fats, and thereby released free fatty acids, which were prone to quicker autoxidation than intact glycerides (Sen, 2011).

Thus, the lower moisture content of Kankrej milk fat can give good keeping quality to the milk fat by preventing occurrence of rancidity in the ghee.

\section{Free Fatty Acids (FFA)}

The free fatty acids content of Kankrej milk fat samples was found to be 0.20 per cent oleic acid (Table 5).
Small portion of fatty acids are always present in fresh milk fat; larger percentage found in the fat isolated from milk or cream that has been subjected to bacterial action or in fat that has been stored for some time. The presence of free fatty acids in unlipolyzed fat may be the result of an incomplete esterification of glycerides in the mammary gland (Kurtz, 1980).

The level of FFA in Kankrej milk fat was lower than the maximum limit suggested by FSSA (2011) (maximum permitted value is 3 per cent as oleic acid) and AG Mark (1938) (maximum permitted value is 3 per cent oleic acid for standard grade ghee) reflecting its quality and freshness.

\section{Total Carbonyl Compounds}

The total carbonyl value for Kankrej milk fat samples ranged from 4.6 to $5.5 \mu \mathrm{m} / \mathrm{g}$ with an average value of $4.9 \mu \mathrm{m} / \mathrm{g}$ (Table 5).

Carbonyl compounds are considered to play an important role in the development of flavor profile of dairy products. Rama Murthy and Jain (1973) observed that total carbonyls in cow milk fat ranged from 4.2 to $4.5 \mu \mathrm{m} / \mathrm{g}$.

\section{Rate of Autoxidation of Kankrej milk fat}

In general, most of fats/oils have reasonably long induction periods under normal condition of their storage. However, induction period, which is a measure of keeping quality of a fat, is influenced by many factors. Therefore, measurement of induction period by accelerated shelf life test is commercially very important to predict the shelf life of oils and fats. In all these tests, the rate of autoxidation is known to increase with the increase in the temperature of reaction and it is assumed that a definite relationship exists between the rate of increase in temperature of storage and rate of increase in autoxidation. 
Therefore, increase of temperature is usually employed in accelerated shelf life tests. Peroxide value is monitored to assess the rate of autoxidation.

In the present study, the rate of autoxidation of Kankrej milk fat samples was assessed by storing the sample at $80 \pm 1^{\circ} \mathrm{C}$ and then analysing them regularly until the peroxide value exceeded 2.6 millimoles of $\mathrm{O}_{2} / \mathrm{kg}$ of fat (BIS 1981). According to BIS the ghee sample having a peroxide value of 2.6 to 3.5 millimoles of $\mathrm{O}_{2} / \mathrm{kg}$, is interpreted as of poor quality. The result of analysis is presented in Table 6.

During accelerated storage $\left(80 \pm 1^{\circ} \mathrm{C}\right)$ study, the peroxide value (millimoles of $\mathrm{O}_{2} / \mathrm{kg}$ of fat) of the sample increased sharply from the $2^{\text {nd }}$ day and continued to increases throughout the storage period. On the $10^{\text {th }}$ day of accelerated storage of ghee at $80 \pm 1^{\circ} \mathrm{C}$, the peroxide value was 2.60 and above, which as per BIS (1981) is interpreted as 'poor quality' So the accelerated storage study was discontinued on reaching this peroxide value. The statistical analysis showed that changes in the peroxide value were not significant for the period of storage (days) as well for experimental samples (milk fat samples) while interaction between period of storage and treatments was non-significant.

Gandhi et al., (2013) in their study reported peroxide value for ghee sample was 10 millimoles of $\mathrm{O}_{2} / \mathrm{g}$ of fat on the $10^{\text {th }}$ day of storage at $80 \pm 1^{\circ} \mathrm{C}$. Parmar et al., (2013) observed that shelf life of Arjuna ghee sample was 8 days at $80 \pm 1^{\circ} \mathrm{C}$ as compared 2 days in the control. Mehta et al., (2015) reported that peroxide value for ghee sample was $6.38 \mathrm{meq}$ of $\mathrm{O}_{2} / \mathrm{kg}$ of fat on the $10^{\text {th }}$ day of storage at 80 $\pm 1^{\circ} \mathrm{C}$. Vaghela (2017) reported that peroxide value for ghee sample was in the range of 3.5 to 4.2 with an average 3.8 millimoles of $\mathrm{O}_{2} / \mathrm{kg}$ of fat on the $10^{\text {th }}$ day of storage at $80 \pm 1^{\circ} \mathrm{C}$.
The rate of autoxidation of Kankrej milk fat observed in the present study was lower than the reported earlier for milk fat stored at $80 \pm$ $1^{\circ} \mathrm{C}$. Kankrej milk fat may have a high concentration of saturated fatty acids and low concentration of unsaturated fatty acids.

\section{References}

Agmark, (1938). Ghee Grading and Marketing Rules (AG MARK). Principle rules published under the notification of the Govt. of India, Imperial council of Agricultural Research No.F- 51-(45)38/ G. I. Dated 29-7-38 in the Gazette of India, Part- I dated 30-7-38.

Bindal, M. P. and Jain, M. K. (1973). A note on the unsaponifiable matter of ghee and its quantitative relationship with cholesterol content. J. Anim. Sci., 43: 900-902.

Bureau of Indian Standards Handbook (BIS: Part XI, 1981). Handbook of Food analysis, Dairy Products. Indian Standards Institution, Manak Bhavan, New Delhi.

Changade, S. P., Tambat, R. V. and Kanoje, R. R. (2006). Physical proporties of ghee prepared from high acidic milk-II. J. dairying, foods \& home sci., 25 (2): 101-104.

Deshpande, S., Deshpande, A. and Tupkari, S. (2008). Shata- dhauta- ghrita - A case study. Indian Journal of Traditional knowledge. 8(3): 387-391.

Dhurvey, Y. R., Kawtikwar, P. S. and Sakarkar, D. M. (2012). Evaluation of Physicochemical Properties of Cow Ghee before and after Hydrogenation. Int. J. Chemtech Res., 4(1): 185-189.

FAO/WHO, (1988). Requirements of Vitamin A, Iron, Folate and Vitamin B12, FAO Food and Nutrition Series. 23. FAO, Rome. 
FSSA (2011). Food Safety and Standards (Food Product Standards and Food Additives) Regulations, Food Safety and Standard Authority of India, Ministry of Health and Family Welfare, Government of India, New Delhi.

Gandhi, K., Pawar, N., Kumar, A. and Arora S. (2013). Effect of Vidarikand (Extracts) on Oxidative Stability of Ghee: A Comparative Study. J. Dairy Sci. Tech., 2(1): 1-10.

German, J. B. and Dillard, C. J. (2013). Composition, Structure and Absorption of Milk Lipids: A Source of Energy, Fat-Soluble Nutrients and Bioactive Molecules. Crit. Rev. Food Sci. Nutr., 46(1): 38-46.

Hulshof, P. J. M., Roekel-Jansen, T. V., Bovenkamp, P. V. and West, C. E. (2006). Variation in retinol and carotenoid content of milk and milk products in The Netherlands. J. Food Compos. Anal., 19: 67-75.

Institute of Medicine, (2001). Dietary Reference Intakes for Vitamin A, Vitamin K, Arsenic, Boron, Chromium, Copper, Iodine, Iron, Manganese, Molybdenium, Nickel, Silicon, Vanadium, and Zinc. National Academy Press, Washington, DC.

Jenness, R. and Patton, S. (1969). Milk Lipid: Principles of Dairy Chemistry. John Wiley \& Sons, PP. 30-72.

Kempanna, C. and Unnikrishnn, V. (1986). The role of carotene in oxidative stability of ghee. Indian J. Dairy Sci., 39: 329-320.

Kumar, M., Sharma, V., Lal, D., Kumar, A. and Seth, R. (2010). A comparison of the physico-chemical properties of lowcholesterol ghee with standard ghee from cow and buffalo creams. Int. $J$. Dairy Tech., 63(2): 252-255.

Kurtz, F. E. (1980). The lipid of milk: Composition and properties: Fundamentals of Dairy chemistry. The
AVI Publishing Company, Inc., Westport, Connectcut, pp.171-213.

Meghwal, K., Sharma, V., Lal, D. and Arora, S. (2012). Effect of cholesterol removal on the granulation behaviour of lowcholesterol ghee. Int. J. Dairy Tech., 65: 1-5.

Mehta, B. M., Darji, V. B. and Aparnathi, K. D. (2015). Comparison of five analytical methods for the determination of peroxide value in oxidized ghee! Food Chem., 185: 449-453.

Parmar, P., Kaushik, K., Devaraja, H. C. and Singh, R. R. B. (2013). The effect of alcoholic extract of Arjuna (Terminalia arjuna wight and Arn.) bark on stability of clarified butter fat. African J. Dairy Farming and Milk Prod., 1(5): 96-100.

Rafalowski, R., Zegarska, Z., Kuncewicz, A. and Borejszo, Z. (2014). Oxidative stability of milk fat in respect to its chemical composition. Int. Dairy J., 36: 82-87.

Rama Murthy, M. K. and Jain, M. K. (1973). Modification of Schwartz method for the estimation of carbonyls in ghee. Indian J. of Anim. Sci., 43: 116-119.

Sen, M. (2011). Effect of addition of antioxidants (BHA and TBHQ) on the stability of poly-unsaturated fatty acids and prevention of cholesterol oxidationproducts formation in ghee during storage and heating. M. Tech. thesis submitted to the National Dairy Research Institute, Karnal, India.

Sharma, S. K. (1989). Studies on unsaponifiable mater ofghee (clarified bunerfat and animal body fats with a view to detect adulteration. Ph.D thesis Submitted to National Dairy Research Institute, Karnal, India.

Steel, R. G. D. and Torrie, J. H. (1980). Principles and procedure of statistics- a biometrical approach. Japan: Mcgraw Hill Kogakusha Ltd., Japan, pp: 137. 
Surendra Nath, B. and Rama Murthy, M. K. (1983). Autoxidative stability of cow and buffalo milk fat triglycerides as influenced by other minor lipid constituents. Indian J. of Dairy Sci., 36:151-156.

Vaghela, K. D. (2017). Detection of oxidative rancidity in ghee at an early stage. $M$.
Tech. thesis submitted to Anand Agricultural University, Anand, India.

Wadhwa, B. K. and Jain M. K. (1989). What make lipid so important in flavour of dairy products. Indian Dairyman, 41: 241.

Wadhwa, B. K. and Jain M. K. (1990). Chemistry ghee flavour - a review. Indian J. of Dairy Sci., 43: 601-607.

\section{How to cite this article:}

Minal Bharwade, Smitha Balakrishnan and Nisha Chaudhary. 2018. Chemical Constituents and Autoxidative Stability of Milk Lipids of Kankrej Cow. Int.J.Curr.Microbiol.App.Sci. 7(03): 1732-1742. doi: https://doi.org/10.20546/ijcmas.2018.703.205 